\title{
Lexis
}

Journal in English Lexicology

$10 \mid 2017$

The Expression of Intensity

\section{Intensification and deintensification in Modern Greek verbs}

Angeliki Efthymiou

\section{(2) OpenEdition}

Journals

\section{Electronic version}

URL: http://journals.openedition.org/lexis/1089

DOI: $10.4000 /$ lexis. 1089

ISSN: 1951-6215

\section{Publisher}

Université Jean Moulin - Lyon 3

Electronic reference

Angeliki Efthymiou, «Intensification and deintensification in Modern Greek verbs », Lexis [Online], 10 | 2017, Online since 30 September 2017, connection on 01 May 2019. URL : http:// journals.openedition.org/lexis/1089; DOI : 10.4000/lexis.1089

This text was automatically generated on 1 May 2019.

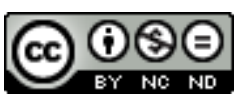

Lexis is licensed under a Creative Commons Attribution-NonCommercial-NoDerivatives 4.0 International License. 


\title{
Intensification and deintensification in Modern Greek verbs
}

\author{
Angeliki Efthymiou
}

I would like to thank the two anonymous reviewers for their helpful and constructive comments and suggestions that greatly contributed to improving the paper.

\section{Introduction}

1 Evaluative (i.e. intensifying and deintensifying) morphemes attached to verbs are quite frequent in Modern Greek. As is cross-linguistically common, they not only indicate deviation from the default value denoted by the base, but can also express a range of meanings such as the negative or positive attitude of the speaker, mitigation, emotional involvement, pluractionality, etc. (see among others Dressler \& Merlini Barbaresi [1994], Grandi [2005] and [2009], Fradin \& Montermini [2009], Stekauer, Valera \& Körtvelyessy [2012], Katunar [2013], Amiot \& Stosic [2014], Weidhass \& Schmid [2015]; for discussion of the notion of intensification, see also Bordet \& Jamet [2015]). The basic characteristics of these evaluative elements include, among others, the following: Firstly, they change the semantics of the base by expressing some deviation from the norm or standard denoted by the base. Secondly, they can often function as free variants, hence it is possible to find examples where these morphemes seem interchangeable: e.g. kutso-vlépo 'to see poorly', psilo-vlépo 'to see a bit' miso-vlépo 'to see but not well'. Thirdly, it is not easy to distinguish their quantitative/measurative dimension from the qualitative/appreciative one or to give explicit descriptive paraphrases of them that fully capture their semantic content.

2 In this paper, we aim to provide a detailed, data-based discussion of the morphological means of evaluation (intensification and deintensification) in Modern Greek deverbal verbs and show that Modern Greek is fairly rich in this domain. This paper is divided into three sections. The first section offers a detailed description of evaluative (intensifying and deintensifying) morphemes attached to verbs in Modern Greek. In the first section we discuss the characteristics of these morphological means and show that Modern Greek 
evaluative morphemes attached to verbs form a well-structured degree system whose distribution is largely determined by linguistic factors. Finally, the second section summarizes the findings of the study.

\section{Modern Greek intensifying and deintensifying morphemes attached to verbs}

Modern Greek has quite a large number of intensifying and deintensifying (attenuating) morphemes (affixes and affixoids) at its disposal ${ }^{1}$. These are listed, along with examples in tables 1 and 2 (see also Efthymiou [2017], forthcoming)

Table 1: The morphological means of attenuation (deintensification) in Modern Greek deverbal verbs

\begin{tabular}{|c|c|c|}
\hline affix/affixoid & derivative & base \\
\hline $\begin{array}{l}\text { ipo- } \\
\text { 'under' }\end{array}$ & $\begin{array}{l}\text { ipo-xrimatodoto } \\
\text { 'to fund inadequately' }\end{array}$ & $\begin{array}{l}\text { xrimatodoto } \\
\text { 'to fund, } \\
\text { finance' }\end{array}$ \\
\hline $\begin{array}{l}\text { miso- } \\
\text { 'half' }\end{array}$ & $\begin{array}{l}\text { miso-Aimáme } \\
\text { 'to remember but not very well' }\end{array}$ & $\begin{array}{l}\text { Oimáme } \\
\text { 'to remember' }\end{array}$ \\
\hline $\begin{array}{l}\text { psilo- } \\
\text { ‘slim’ }\end{array}$ & $\begin{array}{l}\text { psilo--Aimóno } \\
\text { 'to get a bit angry' }\end{array}$ & $\begin{array}{l}\text { Өimóno } \\
\text { 'to get angry' }\end{array}$ \\
\hline $\begin{array}{l}\text { kutso- } \\
\text { 'lame, gimpy’ }\end{array}$ & $\begin{array}{l}\text { kutso-vlépo } \\
\text { 'to see poorly' }\end{array}$ & $\begin{array}{l}\text { vlépo } \\
\text { 'to see' }\end{array}$ \\
\hline $\begin{array}{l}\text { psefto- } \\
\text { 'false' }\end{array}$ & $\begin{array}{l}\text { psefto-Sjavázo } \\
\text { 'to study half-heartedly' }\end{array}$ & $\begin{array}{l}\text { Sjavázo } \\
\text { 'to study/read' }\end{array}$ \\
\hline $\begin{array}{l}\text { xazo- } \\
\text { ‘stupid' }\end{array}$ & $\begin{array}{l}\text { xazo-Sulévo } \\
\text { 'to work half-heartedly' }\end{array}$ & $\begin{array}{l}\text { Sulévo } \\
\text { 'to work' }\end{array}$ \\
\hline $\begin{array}{l}\text { poli- } \\
\text { 'much' (with } \\
\text { negation) }\end{array}$ & $\begin{array}{l}\text { Sen poli-katalavéno } \\
\text { 'lit. not+ much +understand, I do not understand } \\
\text { well' }\end{array}$ & $\begin{array}{l}\text { katalavéno } \\
\text { 'to understand' }\end{array}$ \\
\hline $\begin{array}{l}\text { kalo- } \\
\text { 'well' (with negation) }\end{array}$ & $\begin{array}{l}\text { Sen kalo-kséro } \\
\text { 'lit. not+ well +know, I do not know that much' }\end{array}$ & $\begin{array}{l}\text { kséro } \\
\text { 'to know' }\end{array}$ \\
\hline
\end{tabular}

Table 2: The morphological means of intensification in Modern Greek deverbal verbs

\begin{tabular}{|l|l|l|}
\hline affix/affixoid & derivative & base \\
\hline
\end{tabular}




\begin{tabular}{|c|c|c|}
\hline $\begin{array}{l}\text { iper- } \\
\text { 'over' }\end{array}$ & $\begin{array}{l}\text { iper-fortóno } \\
\text { 'to overload' }\end{array}$ & $\begin{array}{l}\text { fortóno } \\
\text { 'to load }\end{array}$ \\
\hline $\begin{array}{l}\text { para- } \\
\text { 'close to, excessive' }\end{array}$ & $\begin{array}{l}\text { para-cimáme } \\
\text { 'to oversleep' }\end{array}$ & $\begin{array}{l}\text { cimáme } \\
\text { 'to sleep' }\end{array}$ \\
\hline $\begin{array}{l}\text { kata- } \\
\text { 'down(wards), towards' }\end{array}$ & $\begin{array}{l}\text { kata-spataló } \\
\text { 'to waste completely' }\end{array}$ & $\begin{array}{l}\text { spataló } \\
\text { 'to waste' }\end{array}$ \\
\hline $\begin{array}{l}\text { kara- } \\
\text { (<Turkish kara 'black') }\end{array}$ & $\begin{array}{l}\text { kara-zilévo } \\
\text { 'to be extremely jealous' }\end{array}$ & $\begin{array}{l}\text { zilévo } \\
\text { 'to be jealous' }\end{array}$ \\
\hline $\begin{array}{l}\text { apo- } \\
\text { 'away from, } \\
\text { reversative' }\end{array}$ & $\begin{array}{l}\text { apo-kseréno } \\
\text { 'to make completely dry' }\end{array}$ & $\begin{array}{l}\text { kseréno } \\
\text { 'to dry' }\end{array}$ \\
\hline $\begin{array}{l}\text { kse- } \\
\text { 'out of, reversative' }\end{array}$ & $\begin{array}{l}\text { kse-treléno } \\
\text { 'to make someone very mad' }\end{array}$ & $\begin{array}{l}\text { treléno } \\
\text { 'to make someone } \\
\text { mad' }\end{array}$ \\
\hline $\begin{array}{l}\text { scilo- } \\
\text { 'dog' }\end{array}$ & $\begin{array}{l}\text { scilo-varjéme } \\
\text { 'lit. dog+ be bored, to be bored to death' }\end{array}$ & $\begin{array}{l}\text { varjéme } \\
\text { 'to be bored' }\end{array}$ \\
\hline $\begin{array}{l}\text { xilio- } \\
\text { 'thousand' }\end{array}$ & $\begin{array}{l}\text { xilio-exfaristó } \\
\text { 'lit. thousand+ thank, to be deeply grateful' }\end{array}$ & $\begin{array}{l}\text { exfaristó } \\
\text { 'to thank' }\end{array}$ \\
\hline $\begin{array}{l}\text { mirjo- } \\
\text { 'ten thousand' }\end{array}$ & $\begin{array}{l}\text { mirjo-efxaristó } \\
\text { 'lit. ten thousand+ thank, to be deeply } \\
\text { grateful' }\end{array}$ & $\begin{array}{l}\text { exfaristó } \\
\text { 'to thank' }\end{array}$ \\
\hline $\begin{array}{l}\text {-voló } \\
\left(<\mathrm{AG} \beta \alpha \alpha^{\prime} \lambda \lambda \omega \text { 'throw') }\right.\end{array}$ & $\begin{array}{l}\text { kserno-voló } \\
\text { 'to throw up repeatedly' }\end{array}$ & $\begin{array}{l}\text { ksernáo } \\
\text { 'to throw up' }\end{array}$ \\
\hline $\begin{array}{l}\text {-kopó } \\
\text { (<AG kó } \pi \tau \omega \text { 'cut') }\end{array}$ & $\begin{array}{l}\text { vromo-kopó } \\
\text { 'to stink intensively' }\end{array}$ & $\begin{array}{l}\text { vromáo } \\
\text { 'to stink' }\end{array}$ \\
\hline $\begin{array}{l}\text {-manó } \\
(<\mathrm{AG} \mu \alpha i ́ v o \mu \alpha \mathrm{l} \text { 'be mad') }\end{array}$ & $\begin{array}{l}\text { fiso-manó } \\
\text { 'to blow intensively' }\end{array}$ & $\begin{array}{l}\text { fisáo } \\
\text { 'to blow' }\end{array}$ \\
\hline
\end{tabular}

4 As illustrated in tables 1 and 2, what all these morphemes have in common is that they express a deviation from an assumed norm. In the following sections I focus on these two different facets of evaluation: deintensification (attenuation) and intensification. As will be shown, some of the evaluative (intensifying or deintensifying) elements under investigation can combine with bases belonging to a wide variety of grammatical categories (e.g. psilo-, miso-, iper-, ipo-) or registers (e.g. miso-, para-), while others select (or require) bases which belong to a specific grammatical category (e.g. scilo-, para-) or register (e.g. scilo-, iper-, ipo-) or require bases with specific semantic properties (e.g. kata-, scilo-, poli-). Furthermore, it will be shown that some of the elements under investigation 
also have a range of meanings beyond intensification or deintensification, covering mitigation, emotional involvement or other non-evaluative meanings (see e.g. the prepositional prefixes iper-, ipo-, para- and kata- or the affixoids scilo-, psilo- and -volo).

\subsection{Deintensifying prefixes and prefixoids}

As can be seen in table 1, the only deintensifying prefix is ipo- 'under', i.e. a prepositional prefix, which has developed evaluative meanings through grammaticalisation and refunctionalisation ${ }^{3}$. This prefix is usually used in neological loan translations, especially in scientific and technical domains, and creates words belonging to a large variety of grammatical categories (see examples 1a-d). It typically combines with [+learned] or [+/learned] bases ${ }^{4}$. Its semantic contribution is to express the meaning of insufficiency (i.e. 'under the standard or the threshold denoted by the base') without any emotional overtones.

(1) a. ipo-ektimó 'to underestimate'

b. ipo-vitamínosi 'hypovitaminosis'

c. ipo-apasxólisi 'underemployment'

d. ipo-sitizménos 'undernourished'

Psilo- 'slim', miso- 'half', kutso- 'lame, gimpy', psefto- 'false', xazo- 'stupid', poli- 'many, much' kalo- 'good, well' are prefixoids (or prefix like elements), i.e. elements, which have developed a new more general and abstract meaning through grammaticalization ${ }^{5}$. As illustrated in table 1, all these elements, in their bound use, do not behave like parts of compounds (with full lexical meaning), but function as prefixes expressing a more subjective (or evaluative) meaning ${ }^{6}$. It is also interesting to note that some of the prefixoids under investigation come from lexical items with a qualifying (and usually negative) meaning (e.g. kutsós 'lame, gimpy', xazós ‘stupid’).

7 We will begin with psilo-, which is highly productive in Modern Greek. This element creates words belonging to a large variety of grammatical categories (see examples 2a-d), but cannot combine with [+learned] bases. It is also worthy to note that psilo- typically occurs in informal or spoken speech (cf. Savvidou's 2012 corpus study). As far as morphosemantics is concerned, psilo- indicates the lower, reduced intensity of the process/activity in question (example 3a), approximation (example $3 b$ ) or has a pragmatic meaning of mitigation (example 3c) (see Giannoulopoulou [2003], Xydopoulos [2009], Savvidou [2012]). According to Savvidou [2012], the most frequent semantic pattern of psilo-is the meaning of mitigation of the force of the utterance.

(2) a. psilo-katalavéno 'to understand something a bit'

b. psilo-xáos 'a bit of chaos'

c. psilo-ilí日ios 'a bit idiot'

d. psilo-makriá 'a bit far away'

(3) a. psilo-Sagóno 'to bite slightly'

b. psilo-kócinos 'reddish'

c. psilo-pino 'I don't want to tell you that I drink (a lot) but I do so'

Like ipo- and psilo-, miso- is also used with adjectival, verbal and participial bases, but it is not found on nominal bases (see example 4a-c). It seems safe to say that miso- is not stylistically restricted. As concerns its semantic contribution in the verbal domain, miso- 
occurs productively on a wide array of base types and indicates the lower/reduced intensity of the event or the property denoted by the base:

(4) a. miso-pálavos 'half-mad'

b. miso-katalavéno 'to understand something in general terms, but not in

detail'

c. miso-cimizménos 'half-asleep' nominal bases and creates derivatives which express depreciation (see example 6a-c). In particular, in the verbal domain, psefto- occurs frequently on verbs denoting activity. As concerns its semantic contribution, psefto- indicates that the process in question is performed with less effort than expected. In addition to expressing the speaker's attitude to the event in question, verbal formations with psefto- can also express event internal pluractionality (for discussion on the relationship between pluractionality and diminutive verbal morphology, see among others Tovena [2011], Amiot and Stosic [2014]; see also example 5c). Xazo- as well expresses qualitative evaluation and pluractionality (see example 7a-b). Like verbs with psefto- and kutso-, deverbal verbs with xazo- emphasize the lower quality of the action in question (along dimensions such as amount of result or frequency or effort) and indicate a downgraded formality of the interaction. Interestingly enough, xazo- is not documented in standard dictionaries (cf. also footnote 1).
(6) a. psefto-Sjavázo 'to study half-heartedly, from time to time'
b. psefto-kaAarízo 'to clean something, but not very thoroughly'
c. psefto-Simokratía 'pseudo-democracy'
(7) a. xazo-Sulévo 'to work half-heartedly, from time to time'
b. xazo-Sjavázo 'to study half-heartedly'

11 Moving now to poli-, we see that this element expresses the meaning of attenuation only with negation (Delveroudi \& Vassilaki [1999]; see examples 8a-b):

(8) a. Sen poli-rotáo 'I hardly ask'

b. Sen poli-katalavéno 'I barely understand'

Verbs created with poli- are frequently used in informal speech and express lower frequency or intensity of the event in question or minimize the impact of a statement. As Delveroudi \& Vassilaki [1994: 150] aptly put it, a construction involving the combination of negation and prefixation with poli- expresses the meaning 'not much, not exactly, not

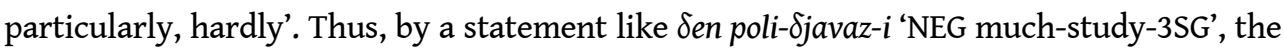


speaker means 'I cannot say that s/he really studies'. The same behavior is attested with the moderately productive element kalo- (see Babiniotis [1969]). Like poli-, kalo- appears only in negative statements (see examples 9a-b):

(9) a. Sen kalo-kséro 'I hardly know'

b. Sen kalo-Oimáme 'I hardly remember'.

Its semantic contribution is to indicate the lower/reduced intensity of the event in question.

\subsection{Intensifying prefixes and affixoids}

14 As can be seen in Table 2, half of the intensifying elements used to form verbs in Modern Greek are prefixes (iper-, para-, kata-, kara-, apo-, kse-). Most of them exhibit extensive polysemy and derive words of more than one grammatical categories (see examples 10ae) (Efthymiou [2002, 2003], Efthymiou, Fragaki \& Markos [2015a, b])7.

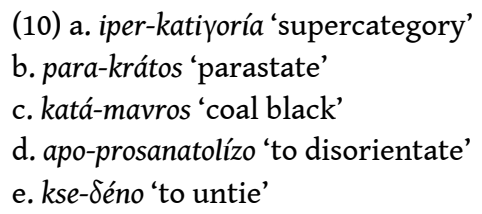

Intensifying prefixes can be grouped according to their etymology:

those that derive from Ancient Greek prepositions (iper-, para-, kata-, apo-),

those that are of non-native origin (kara-, which originates from the Turkish adjective kara 'black'), and

those that are formations of Medieval Greek (kse-, which developed from the combination of the Ancient Greek preverb $e k$ - with the verbal syllabic augment $\left.e^{-}\right)^{8}$.

Iper- occurs productively on telic verbs with incremental theme (see examples 10a-b.), even if it is also found with atelic verbs, which express situations with no natural endpoint (examples 11a-d).

(11) a. iper-fortóno 'to overload',

b. iper-Oerméno 'to overheat'

c. iper-ayapó 'to love very much'

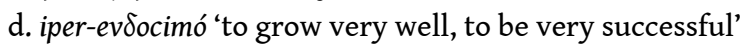

Its semantic contribution is to denote the notion of excess (i.e. "more than normal or desirable') or the meaning of high degree (i.e. 'very, extremely x'), without any emotional overtones (Efthymiou [2003], Gavriilidou [2014], Efthymiou, Fragaki \& Markos [2015a]). The prefix occurs on [+learned] or [+/-learned] bases.

On the other hand, para- attaches to a wide array of verb types (examples 12a-e), but cannot combine with [+ learned] bases (see example 12) (Efthymiou [2003, 2016], Gavriilidou [2014], Efthymiou, Fragaki \& Markos [2015b]).

(12) a. para-káno 'to overdo, to do something too much'

b. para-xrisimopió 'overuse'

c. para-jemízo 'to overfill'

d. para-miló 'to talk too much'

e. para-éxo 'to have something to excess' 
(13) *para-meje日íno vs. iper- meje日íno 'to enlarge to excess'

19 As concerns its semantic contribution, para- is extremely productive in the meaning of excess. Many of the deverbal derivatives with para- also express periphrastic reinforcement, upgrading the determinacy of the propositional content of the verb (see example 13) (Efthymiou, Fragaki \& Markos [2015b]).

(14) iksere ce para-iksere 'he/she knew and he/she knew very well' with negatively connotated verbal bases and/or atelic verbs and derives words with negative connotations (see examples 14a-d):

(15) a. kata-spataló 'to squander completely'

b. kata-trómaksa 'I was scared to death'

c. kata-stenaxorjéme 'get extremely sad'

d. kata-kurázo 'to tire completely'

21 As far as morphosemantics is concerned, kata- denotes the meaning of 'absolute completeness' (Delveroudi \& Vassilaki [1994], Efthymiou [2003, 2017], Gavriilidou [2014], Kallergi [2015]).

The prefixes apo- and kse- are barely productive in the semantic domain of intensification. According to the data of this study, neologisms with apo- are rarely attested. Furthermore, our data show that there are no attested neologisms with kse-. Apo - usually attaches to telic verbs with incremental theme, and creates verbs that denote completion of the event. Furthermore, the verbs which serve as bases for the intensifying apo- have very often negative connotations (see example 15a-c):

(16) a. apo-kseréno 'to make completely dry'

b. apo-tiflóno 'to make someone completely blind'

c. apo-treléno 'to make someone completely mad'

On the other hand, the intensifying prefix kse- is typically attached to negatively connotated bases in order to create verbs with the meaning 'very, extremely $\mathrm{x}$ ' (Efthymiou [2002, 2003], Kallergi [2015]):

(17) a. kse-treléno 'to make someone very mad'

b. kse-puló 'to sell out, to bargain away'

The moderately productive prefix kara- is used in highly informal register and derives [learned] words with negative connotations ${ }^{9}$. As concerns its semantic contribution in the verbal domain, the prefix is exclusively intensifying, expressing both quantitative and qualitative evaluation. Kara- typically combines with verbs denoting emotion, and expresses a very high degree of intensification (i.e. the meaning very, extremely $x^{\prime}$ ) (Minas [1978], Fotiou [1998]). It also indicates at the same time the negative attitude or the emotional involvement of the speaker or expresses overstatement (Efthymiou [2017], forthcoming):

(18) a. kara-drépome 'to be extremely ashamed'

b. kara-үustáro 'to fancy extremely, enjoy extremely'

c. kara-simba日ó 'to get to like someone extremely' 
The analysis conducted so far has revealed that in Modern Greek evaluative verbs the
meaning of deintensification is almost always expressed by prefixoids (e.g. psilo-, kutso-),
while the meaning of intensification is mostly expressed by prepositional prefixes (e.g.
iper-, para-). Moreover, the discussion of the properties of the morphemes studied here
has shown that Modern Greek evaluative morphemes attached to verbs are not identical
in productivity (see e.g. the difference in productivity between para- and kse-). The
distribution of intensifying and deintensifying prefixes according to their position with

The analysis conducted so far has revealed that in Modern Greek evaluative verbs the
meaning of deintensification is almost always expressed by prefixoids (e.g. psilo-, kutso-),
while the meaning of intensification is mostly expressed by prepositional prefixes (e.g.
iper-, para-). Moreover, the discussion of the properties of the morphemes studied here
has shown that Modern Greek evaluative morphemes attached to verbs are not identical
in productivity (see e.g. the difference in productivity between para- and kse-). The
distribution of intensifying and deintensifying prefixes according to their position with

The analysis conducted so far has revealed that in Modern Greek evaluative verbs the
meaning of deintensification is almost always expressed by prefixoids (e.g. psilo-, kutso-),
while the meaning of intensification is mostly expressed by prepositional prefixes (e.g.
iper-, para-). Moreover, the discussion of the properties of the morphemes studied here
has shown that Modern Greek evaluative morphemes attached to verbs are not identical
in productivity (see e.g. the difference in productivity between para- and kse-). The
distribution of intensifying and deintensifying prefixes according to their position with

The analysis conducted so far has revealed that in Modern Greek evaluative verbs the
meaning of deintensification is almost always expressed by prefixoids (e.g. psilo-, kutso-),
while the meaning of intensification is mostly expressed by prepositional prefixes (e.g.
iper-, para-). Moreover, the discussion of the properties of the morphemes studied here
has shown that Modern Greek evaluative morphemes attached to verbs are not identical
in productivity (see e.g. the difference in productivity between para- and kse-). The
distribution of intensifying and deintensifying prefixes according to their position with

The analysis conducted so far has revealed that in Modern Greek evaluative verbs the
meaning of deintensification is almost always expressed by prefixoids (e.g. psilo-, kutso-),
while the meaning of intensification is mostly expressed by prepositional prefixes (e.g.
iper-, para-). Moreover, the discussion of the properties of the morphemes studied here
has shown that Modern Greek evaluative morphemes attached to verbs are not identical
in productivity (see e.g. the difference in productivity between para- and kse-). The
distribution of intensifying and deintensifying prefixes according to their position with

The analysis conducted so far has revealed that in Modern Greek evaluative verbs the
meaning of deintensification is almost always expressed by prefixoids (e.g. psilo-, kutso-),
while the meaning of intensification is mostly expressed by prepositional prefixes (e.g.
iper-, para-). Moreover, the discussion of the properties of the morphemes studied here
has shown that Modern Greek evaluative morphemes attached to verbs are not identical
in productivity (see e.g. the difference in productivity between para- and kse-). The
distribution of intensifying and deintensifying prefixes according to their position with

(21) a. kserno-voló 'to throw up repeatedly'

b. vromo-kopó 'to stink intensively'

c. fiso-manó 'to blow intensively'

(19) a scilo-varjéme 'to be bored to death'

b. scilo-pináo 'to be damn hungry'

c. scilo-vrízo 'to offend deeply'

(20) a. xilio-efxaristó 'to thank a million, to be deeply grateful'

b. xilio-bálosa 'I patched something many times'

c. mirjo-parakaló 'to beg' elements are etymologically related to Ancient Greek verbs (i.e. $\beta \alpha \alpha \lambda \lambda \omega$ 'throw', кóm $\tau \omega$

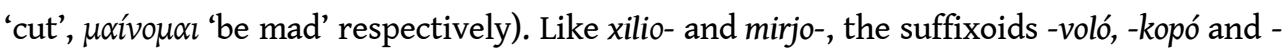
manó are not productive in contemporary Greek. As concerns their semantic contribution, these suffix-like elements express the meaning of high degree (i.e. 'very, extremely $\left.\mathrm{x}^{\prime}\right)$ :

indicate the negative or positive attitude of the speaker or express exaggeration (Efthymiou [2017], forthcoming).

\section{The expression of evaluation in Modern Greek deverbal verbs}

Lexis, 10 | 2017 
regard to the base is presented in table 3. Unproductive morphological means of intensification or deintensification are noted here by one star (see also discussion in previous section).

Table 3: The morphological means of evaluation (intensification and deintensification) in Modern Greek deverbal verbs

\begin{tabular}{|c|c|}
\hline $\begin{array}{l}\text { Intensification and } \\
\text { Verbs }\end{array}$ & sification in Modern Greek \\
\hline $\begin{array}{l}\text { INTENSIFICATION } \\
\text { (12 morphemes) }\end{array}$ & $\begin{array}{l}\text { DEINTENSIFICATION } \\
\text { (8 morphemes) }\end{array}$ \\
\hline Prefixes & Prefixes \\
\hline iper- & ipo- \\
\hline para- & - \\
\hline kata- & - \\
\hline kara- & - \\
\hline apo- * & - \\
\hline$k s e^{*}$ & - \\
\hline Prefixoids & Prefixoids \\
\hline scilo- & miso- \\
\hline xilio-* & psilo- \\
\hline mirjo-* & kutso- \\
\hline- & psefto- \\
\hline- & xazo- \\
\hline- & poli-(with negation) \\
\hline- & kalo-(with negation) \\
\hline Suffixoids & Suffixoids \\
\hline -voló* & - \\
\hline -kopó* & - \\
\hline$-m a n o^{*}$ & - \\
\hline
\end{tabular}



quantitative or qualitative evaluation, pluractionality, mitigation of the force of the utterance, overstatement, emotional involvement, etc. More specifically, with respect to their semantic contribution in derived verbs, Modern Greek evaluative morphemes can be distinguished into three types (see also Efthymiou forthcoming):

those that are typically associated with quantitative evaluation (e.g. ipo-, iper-, miso-, manó),

those that typically combine both quantitative and qualitative meanings, indicating the negative or positive attitude of the speaker or (e.g. kutso-, psefto-, kata-), and

those that are typically associated with an emotive or pragmatic meaning (e.g. psilo-, kara-, scilo-).

It is also notable that several of the evaluative morphemes under investigation (e.g. kata-, scilo-, kutso-, kse-) seem to have a negative semantic prosody (see among others Partington [1988]), being surrounded by negative lexis (i.e. words with negative attitudinal meanings) or attaching to negatively connotated bases (cf. Efthymiou 
forthcoming): e.g. Tus sciló-vrise ce tus kata-prósvale 's/he swore at them very badly and greatly insulted them' (example taken from Kallergi [2015: 322]) ${ }^{10}$.

Moving to the domain of deintensifying morphemes, we observe that it is not difficult to find examples where these morphemes seem interchangeable (see also section1), with very little difference in meaning ${ }^{11}$ :

(22) a. psefto- $\gamma$ ráfo 'to write in a leisurely, way from time to time'

b. kutso- $\gamma$ ráfo 'to write slowly, poorly'

c. psilo- $\gamma$ ráfo 'to write a bit'

d. Sen poli- $\gamma$ ráfo 'I hardly write'

However, a more detailed investigation of the semantic properties of these deintensifying morphemes reveals that these morphemes are not identical in semantic nuance: kutsoand psefto- are typically associated with qualitative interpretations, emphasizing the lower quality of the action, psilo- is typically associated with the pragmatic meaning of mitigation, and poli- (with negation) is typically associated with the expression of a minimal degree (i.e. 'not exactly, not particularly, hardly'). Moreover, a comparison of psefto- and kutso- reveals that kutso- lacks the semantic feature 'with less effort than expected' that psefto- typically caries. Similar remarks can be made for Modern Greek intensifying morphemes. For example, kata- and kara- share the meaning of intensification and derive words with negative connotations:

(23) a. kata-stenaxorjéme 'get extremely sad'

b. kara-stenaxorjéme 'get extremely sad'

However, kata- lacks the [highly informal] feature that kara- generally carries (for detailed discussion on Modern Greek intensifying morphemes, see section 1.2.; see also Efthymiou [2003, 2017], forthcoming and Gavriilidou [2014]).

Turning now to the register properties of Modern Greek evaluative morphemes, we can identify three main sets:

morphemes that typically occur in informal or spoken speech: see e.g. the affixoids psilo-, kutso-, scilo-, psefto- and xazo- or the prefix kara-,

morphemes which typically occur in refined or written speech: see e.g. the prepositional prefixes ipo- and iper-, and

morphemes which are not stylistically restricted: see e.g. the prefixoid miso- or the prefixes kata-, apo- and kse-.

This categorization shows that the vast majority of affixoids (e.g. psilo-, kutso-, scilo-, psefto-, xazo-) typically have a colloquial usage, while prepositional prefixes may be either stylistically unrestricted (e.g. kata-, apo-) or they may have a scientific usage (e.g. ipo-, iper -) (for discussion on the register factors or speech situations which favor the use of evaluative morphemes, see among others Dressler and Merlini Barbaresi [1994], Gaeta [2015]).

\section{Concluding remarks}

46 To sum up, in the domain of verbs, Modern Greek evaluative morphemes form a structured set of intensifiers and deintensifiers with a primary function of denoting degrees of intensity. Most of these morphemes also have a range of meanings beyond 
intensification or deintensification, covering the negative or positive attitude of the speaker, mitigation, emotional involvement or other non-evaluative meanings. It is also shown that the variation we find in evaluative derivational processes is largely determined by linguistic factors (e.g. selectional constraints, differences in meaning or register) and that each evaluative morpheme is rather potentiating within a certain domain.

\section{BIBLIOGRAPHY}

ANASTASSIADIS-SYMEONIDIS Anna \& FLIATOURAS Asimakis, 2003, “The features [learned] and [learned] in Greek: Definition and classification", Proceedings of the $6^{\text {th }}$ International Conference on Greek Linguistics, University of Crete, available at: http://www.philology.uoc.gr/ conferences/6thICGL/gr.htm. [in Greek].

Аміот Dany \& Sтоsic Dejan, 2014, "When evaluative morphology, pluractionality and aspect get tangled up: a case study of French suffixed verbs", in GAVRIILIDOY Zoe \& REVITHIADOU Anthi (eds.), Mélanges offerts à Anna Anastassiadis-Syméonidis. Kavala: Saita Publishers, 16-33.

BABINIOTIS Georgios, 1969, Diminution and compounding. Ph.D. Thesis. Athens: University of Athens. [in Greek]

BABINIOTIS, Georgios, 2002, Dictionary of Modern Greek. Athens: Lexicology Centre.

BAUER Laurie, 1997, "Evaluative morphology: in search of universals", Studies in Language 21.3, 533-575.

BORDET Lucile \& JAMET Denis, 2015, « Degré et intensification : essai de typologie », Anglophonia 20, http://anglophonia.revues.org/549.

CORBIN Danielle, 1999, « Pour une théorie sémantique de la catégorisation affixale », Faits de Langues 14, 65-77.

DELVEROUdi Rea \& VASSILAKI Sophie, 1999, «Préfixes d'intensité en grec moderne : para-, kata-, poly - et olo- ", in DESCHAMPS Alain \& GUILLEMIN-FLESCHER Jacqueline (eds.), Les Opérations de Détermination: Quantification/Qualification, Paris: Ophrys, 149-167.

Dimela Eleonora \& MELISSARopoulou Dimitra, 2009, "On prefix like adverbs in Modern Greek", Patras Working Paper in Linguistics 1, 72-94.

DRESSLER Wolfgang \& MERLINI-BARBARESI Lavinia, 1994, Morphopragmatics: Diminutives and Intensifiers in Italian, German and Other Languages. Berlin: Mouton de Gruyter.

еғтнуміоu Angeliki, "Semantic considerations for the Modern Greek prefixes kse-, ek-, apo-", Studies in Greek Language 22, 2002:199-209. [in Greek]

EFTHYMiou Angeliki, 2003, "Prefixes or first elements denoting intensification in Modern Greek", Studies in Greek Linguistics 23, 519-528 [in Greek].

EFTHYMIOU Angeliki, 2015, "Modern Greek diminutive and augmentative adjectives (in a crosslinguistic perspective)”, SKASE Journal of Theoretical Linguistics 21(1), 57-71. 
EFTHYMIOU Angeliki, 2017, "Intensification and attenuation in Modern Greek evaluative verbs", Studies in Greek Language 37, 227-238. [in Greek].

EFTHYMIOU Angeliki, 2016, “On the polysemy of the Modern Greek prefix para-" in KÖRTVÉLYESSY Livia, ŠTEKAUER Pavol \& VARELA Salvador (eds.), Word-Formation across Languages. Newcastle upon Tyne: Cambridge Scholars Publisher, 91-108.

EFTHYMiOU Angeliki, "Morphological variation in Modern Greek evaluative verbs and adjectives”, in ARCHAKIS, Argiris, KOUTSOUKOS Nikos, XYDOPOULOS, Georgios \& PAPAZACHARIOU Dimitris, Festschrift in Honor of Angela Ralli, forthcoming.

EFTHYMIOU Angeliki, FRAGAKI, Georgia \& MARKOS, Angelos, 2015a, "Exploring the meaning and productivity of a polysemous prefix. The case of the Modern Greek prepositional prefix para-", Acta Linguistica Hungarica 62(4), 447-476.

EFTHYMIOU Angeliki, FRAGAKI, Georgia \& MARKOS, Angelos, 2015b, "Exploring the polysemy of the Modern Greek prefix iper-", Morphology 25(4), 411-438.

FRADIN Bernard \& MONTERMINI, Fabio, 2009, « La morphologie évaluative », in FRADIN Bernard, KERLEROUX Françoise \& PLÉNAT Marc (eds.), Aperçus de morphologie du français, Presses Universitaires de Vincennes, 231-266.

FОтіоU Nikolaos, 1998, Augmentative prefixation and intensification in Modern Greek. Unpublished MA thesis: Aristotle University of Thessaloniki, [in Greek]

GAETA Livio, "Evaluative morphology and sociolinguistic variation", in GRANDI Nicola \& KÖRTVÉLYESSY Livia (eds.), 2015, Edinburgh Handbook of Evaluative Morphology. Edinburgh: Edinburgh University Press, 121-133.

GAVRIILIDOU Zoe, 2014, “The system of intensifying prefixes in Greek”, Lingvistica Investigationes $37: 2,240-255$.

GIANNOULOPOUlOU Giannoula, 2003, "Morphemes in the boundaries between derivation and compounding: The case of theo-, psilo- and -ferno", Proceedings of the $6^{\text {th }}$ International Conference of Greek Linguistics. Rethymno: University of Crete. Available at: http://www.philology.uoc.gr/ conferences/6thICGL/gr.htm. [in Greek].

GRANDI Nicola, 2005, "Sardinian evaluative morphology in typological perspective", in GUTZU Ignatio (ed.), Sardinian in Typological Perspective. Bochum. Dr. Brockmeyer University Press, 188-209.

GRANDI Nicola, 2009, "Restrictions on Italian verbal evaluative suffixes: The role of aspect and actionality", York Papers in Linguistics 2, 46-66.

GRANDI Nicola, 2011, "Renewal and innovation in the emergence of Indo-European Evaluative Morphology", Lexis 6, 5-25.

JURAFSKY Daniel, 1996, “Universal tendencies in the semantics of the diminutive”, Language 72(3), 522-578.

KALLERGI Haritini, 2015, Reduplication at the Word level: The Greek facts in a Typological Perspective. Berlin/Boston: De Gruyter.

KATUNAR Daniela, 2013, "Diminutives in Action: A cognitive account of diminutive verbs and their suffixes in Croatian", Suvremena Lingvistika 39, $\mathrm{n}^{\circ}$ 75, 1-23.

KÖRTVÉLYESSY Livia, 2014, “Evaluative derivation”, in LIEBER Rochelle \& ŠTEKAUER Pavol (eds.), The Oxford Handbook of Derivational Morphology. Oxford: Oxford University Press, 296-316. 
MANOLESSOU Ioanna \& RALLI Angela, "From Ancient Greek to Modern Greek”, in MÜLLER Peter, OHNHEISER Ingeborg, OLSEN Susan \& RAINER Franz (eds), 2015, Word-Formation. An International Handbook of the Languages of Europe, vol 3, Berlin/New York: De Gruyter, 2041-2061.

MENDEZ-DOSUNA Julián, 1997, "Fusion, fission and relevance in language change: De-univerbation in Greek verb morphology", Studies in Language 21 (3), 577-612.

MINAS Konstantinos, 1978, The Morphological Means of Augmentation in Greek Language, Ioannina, University of Ioannina.

MUTZ Katrin, 2015, "Evaluative morphology in a diachronic perspective," in GRANDI Nicola \& KÖRTVÉLYESSY Livia (eds.), Edinburgh Handbook of Evaluative Morphology. Edinburgh: Edinburgh University Press, 142-154.

NAPOLI Maria, 2013, “On Italian past participles with -issimo: The superlative of events between intensification and pluractionality", Linguistica e Filologia 33, 85-126.

PARTINGTON Alan, 1998, Patterns and Meanings: Using Corpora for English Language Research and Teaching. Amsterdam/Philadelphia: Benjamins.

RAINER Franz, “Intensification”, in MÜLLER Peter, OHNHEISER Ingeborg, oLSEN Susan \& RAINER Franz (eds.), 2015, Word-formation. A Handbook of the Languages of Europe. Berlin/New York: De Gruyter, Vol. 2, 1330-1350.

RALLI Angela, 2014, "Stem-based versus word-based morphological configurations: The case of Modern Greek preverbs", Lingue e Linguaggio 2, 241-275.

SAVVIDOU Paraskevi, 2012, "Mitigation and intensification with the use of the morphemes $\theta e o-$ and psilo-. A corpus-based analysis", in GAVRIILIDOu Zoe, EFTHYMIOU Angeliki, THOMADAKI Evangelia \& KAMBAKIS-VougioukuIs Penelope (eds.), 2012, Selected Papers of the 10th International Conference of Greek Linguistics, Komotini, Greece: Democritus University of Thrace, 1090-1099. [in Greek]

ŠTEKAUER Pavol, VALERA Salvador \& KÖRTVÉLYESSY Lívia, 2012, Word-Formation in the World's

Languages, Cambridge: Cambridge University Press.

TRIANDAFYLLIDIS Dictionary, 1998, Standard Modern Greek Dictionary. Institute of Hellenic Studies, Aristotle University of Thessaloniki, [In Greek]

TOVENA Lucia, 2011, "When small is many in the event domain", Lexis 6, 41-58.

XYDOPOULOS Georgios, 2009, “Psilo-: Exploring the case of a 'diminutive' in Modern Greek”, in TSANGALIDIS Anastasios (ed.), Selected Papers from the $18^{\text {th }}$ International Symposium of Theoretical and Applied Linguistics. Thessaloniki: Monochromia, 397-405.

WEIDHAAS Thomas \& SCHMID, 2015, Hans-Jörg, "Diminutive verbs in German: semantic analysis and theoretical implications", Morphology. 25(2), 183-227.

\section{NOTES}

1. Given that electronic corpora of Modern Greek are still relatively small, contain a low percentage of spoken data and are not annotated for morphological purposes, I take as a starting point the analysis of 40 para- and 54 iper- verbs in Efthymiou, Fragaki and Markos's corpus studies [2015a, b] and a list of 160 deverbal evaluative verbs extracted from two Modern Greek dictionaries (Triandafyllidis [1998]; Babiniotis [2002] and electronic sources (Google)). The data of Efthymiou et al [2015 a, b] comes from the Corpus of Greek Texts (CGT), a reference corpus of 
Modern Greek (for a detailed description of CGT, see Goutsos [2010]). Needless to say, the spontaneous attested verbal formations are certainly much more numerous (and/or varied) than what is found (i.e. documented) in dictionaries and Google (cf. Dressler \& Merlini Barbaresi [1994] and Grandi [2009] on the vitality of evaluative morphology).

2. The list of evaluative morphological items presented here can be considered quasi-exhaustive (see also footnote 1).

3. Ipo- is not exclusively deintensifying, but expresses both locational and quantitative meanings

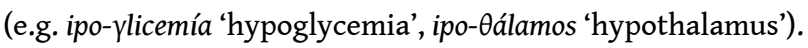

4. Following Anastassiadis-Symeonidis \& Fliatouras [2003], the feature [+learned] is attributed to words that either a) come from Ancient Greek, b) constitute artificial formations of 'katharevousa' (i.e. the artificial, ancient-looking form of Greek developed by scholars in the $19^{\text {th }}$ century) or c) are only used in refined or written speech (cf. also Ralli [2004]). Words characterized as [-learned] either have a popular origin or are used in informal or spoken (colloquial) speech. Finally, the feature [+/- learned] is ascribed to words that have an unmarked use or origin (i.e. they are neither learned nor non-learned).

5. The status of these morphemes as affixoids (i.e. elements that are in process of being grammaticalized, gradually losing their lexical status and behaving more or less like affixes) is not uniform and entails a thorough investigation of each morpheme (for discussion, see among others, Dimela \& Melissaropoulou [2009]). However, discussing the morphological status of these morphemes in detail goes beyond the scope of the present paper.

6. Examples of words constructed with the above mentioned prefixoids without attenuating meaning are not taken into consideration in the present study.

7. Examples of words constructed with the prefixes iper-, para-, kata-, kara-, apo- and kse-without intensifying meaning or belonging to other grammatical categories are not taken into consideration in the present study (see e.g. iper-katáskopos 'super spy', iper-oceánios 'transoceanic',

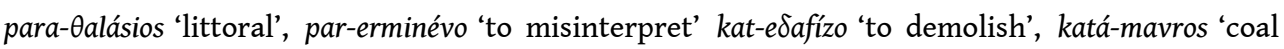
black').

8. According to Mendez-Dosuna [1997], the verbal augment $e$ - was often misanalyzed as part of the prefix in Medieval Greek.

9. The use of kara- as an intensifying prefix probably started from the borrowing of Turkish words where kara was a component with an intensifying function, e.g., Turkish sevda 'love, passion' $\rightarrow$ kara-sevda-ll 'deeply in love (adjective) > Modern Greek karasevda-lis 'id.' (Manolessou and Ralli [2015]).

10. For discussion on the semantic prosody of evaluative morphemes in Greek, see also Savvidou [2012]

11. For similar remarks on the semantic behavior of kutso- and miso- see Dimela and Melissaropoulou [2009].

\section{ABSTRACTS}

This paper aims at examining the morphological means of intensification and deintensification in Modern Greek deverbal verbs. First, it will be shown that in Modern Greek deverbal verbs the meaning of intensification (and deintensification) is almost always expressed by prepositional prefixes or prefixoids: e.g. para-cimáme ‘to oversleep', iper-fortóno 'to overload, scilo-varjéme 'to be 
bored to death' (scilo- 'dog'+ varjéme 'to be bored'), kutso-vlépo 'to see poorly' (kutso- 'lame'+ vlépo 'see'); see also Efthymiou (2017). Secondly, it will be demonstrated that in Modern Greek deverbal verbs the meaning of intensification is mostly expressed by prepositional prefixes, while the meaning of deintensification (attenuation) is almost always expressed by prefixoids. Thirdly, it will be shown that in Modern Greek, the system of intensifying and deintensifying morphemes has emerged via the processes of grammaticalisation (e.g. the prefixization of full lexical items like scilo- 'dog', kutso- 'lame', etc.) and refunctionalisation (e.g. the prepositional prefixes iper-, para-, which have developed evaluative meanings) or via borrowing (e.g. the MG colloquial intensive prefix kara- 'very', from the Turkish adjective kara 'black': kara-tsekáro 'to check very thoroughly'). Finally, it will be suggested that a) the diversity of evaluative derivational processes (e.g. kutso-vlépo 'to see poorly', psilo-vlépo 'to see a bit') is largely determined by linguistic factors (e.g. selectional constraints, differences in meaning, etc.) and that b) each evaluative morpheme under investigation is rather potentiating within a certain domain (e.g. the learned prefix iperexpresses quantitative evaluation, the colloquial prefix kara- has an emotive/pragmatic meaning, etc.).

Le but de cet article est d'examiner les moyens morphologiques d'intensification et détensification dans les verbes déverbaux du grec moderne. Dans un premier temps, nous montrerons que dans les verbes en grec moderne, l'intensification et la détensification est presque toujours exprimée par le biais de préfixes ou de pseudo-préfixes, par exemple : paracimáme 'dormir trop longtemps', iper-fortóno 'surcharger', scilo-varjéme 's'ennuyer à mourir' (scilo'chien'+ varjéme 's'ennuyer'), kutso-vlépo 'avoir une mauvaise vue' (kutso- 'boiteux'+ vlépo 'voir'); voir également Efthymiou (2017). En second lieu, nous montrerons qu'en grec moderne l'intensification est principalement exprimée par le biais de préfixes, alors que la détensification (l'atténuation), s'exprime davantage par le biais de pseudo-préfixes. Puis, nous montrerons qu'en grec moderne, les morphèmes exprimant l'intensification et la détensification ont été obtenus par le biais de processus de grammaticalisation (par exemple, la préfixation d'éléments lexicaux tels que scilo- 'chien', kutso- 'boiteux', etc.) et d'attribution de nouvelles fonctions (par exemple, les préfixes iper-, para-, qui ont développé une valeur évaluative) ou par le biais de l'emprunt (par exemple le préfixe familier kara- 'très', issu de l'adjectif turc kara 'noir': kara-tsekáro 'vérifier consciencieusement'). Finalement, nous ferons l'hypothèse que a) la diversité des processus évaluatifs exprimés par des préfixes (e.g. kutso-vlépo 'avoir des problems de vue', psilo-vlépo 'voir un petit peu') est largement déterminée par des facteurs linguistiques (par exemple, des contraintes morphologiques, des différences sémantiques, etc.) et que b) chaque morphème évaluatif à l'étude est davantage utilisé dans certains domaines que d'autres (par exemple le préfixe savant iper- exprime l'évaluation quantitative, le préfixe familier kara- exprime l'émotion/un sens pragmatique, etc.).

\section{INDEX}

Mots-clés: intensification, détensification, morphèmes évaluatifs, verbes, grec moderne, sens pragmatique, évaluation quantitative/qualitative

Keywords: intensification, deintensification, evaluative morphemes, verbs, Modern Greek, pragmatic meaning, quantitative/qualitative evaluation 


\section{AUTHOR}

\section{ANGELIKI EFTHYMIOU}

Democritus University of Thrace, Greece aefthym@eled.duth.gr 